\title{
Working Capital Management and Level of Countries' Corruption: A Panel Study of ASEAN Countries
}

\author{
Ebrahim Mansoori \\ University of Kurdistan-Hawler
}

Amjad Pirotti

University of Malaya

Andrew Craik

Bluestar AMG Malaysia Limited

Reza Ghazal

Environment and Climate Change-Canada

This paper aims to clarify the relationship between working capital management and the level of countries' corruption. This study uses a large panel sample of five ASEAN countries; Malaysia, Indonesia, Singapore, Thailand, and the Philippines over the period 2005-2017 using Ordinary Least Squares (OLS) estimators. The results indicate that the length of the cash conversion cycle will decrease as a result of increasing the level of corruption indexes. Meanwhile, a high level of corruption indexes forces the managers for the sample firms decrease the level of investment in cash equivalents and cash.

Keywords: working capital management, corruption indexes, ASEAN

\section{INTRODUCTION}

Working capital management is one of the most important task of the financial managers as it affects both the liquidity and profitability of a firm (Shin and Soenen, 1998). Recent studies (Claudiu Boțoc and Sorin Gabriel Anton, 2017; Caballlero et al., 2010; Mansoori and Muhammad, 2012) have shown that reducing the level of working capital would increase the firm's profitability, and consequently, its value. However, further reduction in working capital would not be possible, given that firms have to maintain a sufficient amount of funds and current assets to perform their daily operations. Therefore, managers must balance their level of investment in working capital.

To help managers in doing so, several researchers have provided suggestions for working capital management. Earlier studies (Appuhami, 2008) focused on firm-specific variables, internal variables, to determine working capital management. Such variables are related to the operational conditions and financing capability of the companies that affect the efficiency of working capital management. Other studies (Caballero et al., 2010; Zariyawati, 2010) concentarted on external variables such as macroeconomic variables that affect working capital management. These studies highlighted that access 
to external finance is an important external factor affecting working capital management. Recent studies (Beck and Kunt, 2005; Chen et al., 2014; Fan and Zhao, 2008; La porta et al., 1997) mentioned that level of countries' corruption is an important factor that affect the level of firm's access to external financing, and consequently firms' financing and investment policies. Chen et al., (2014) argued that in cases where corporations are dealing with more corrupt governments, they have to use more resources to access external financing, particularly from the government banks. On the other hand, Fan et al., (2008) reported that firms may use corruption to facilitate their access to external financing. Most likely, the latter would be the case for less-developed countries where corruption facilitates, and not hinder, access to external financing.

Level of corruption would affect the working capital management for several reasons. First, corruption may be one of the obstacles that restrict the access of firms to the external finance especially from banks (Beck et al., 2005). Therefore, the control of corruption can help firms to have better access to external financing. Such improved access encourages managers to increase the level of their investment in working capital (caballero et al., 2014; Chiou and Cheng, 2006; Fazzary and Petersen, 1993). Second, corruption may change the policies on investment. Caprio et al., (2013) empirically showed that the level of investment in fixed assets increases with the increase of the level of corruption. Moreover, they argue that firms hold a lower fraction of assets in cash when the level of corruption is high because liquid assets are easier to extract by state rulers than the fixed ones, such as property, plant, equipment, and inventories. In this context, the control of corruption encourages the managers to increase the level of their investment in current assets, including account receivables and inventories.

Third, corruption reduces economic growth rate, human capital, and the share of private capital, as empirically tested by Hung (2001). Therefore, the control of corruption leads to more economic growth and higher share of private capital, which may increase access of firms to external financing. Fourth, the level of investment flows and cost of capital are affected by corruption (Pankajk and Pagano, 2012). Chen et al., (2014) argued that firms in more corrupt countries have to utilize more resources to access external financing, especially from the governmental banks; consequently, increasing the cost of capital. Hence, the lower level of corruption could reduce the cost of capital and subsequently increase the level of investment in the working capital.

Consolidating all these different arguments, investigating the effects of corruption as one external factor on working capital management is worth considering. In this context, this research enriches the existing literature on the effect of corruption on the working capital management of firms by considering a firm-level data for five ASEAN countries. The different political systems of the countries under the study allows us to capture the effects of corruption very well. In particular, this study identifies the relationship between corruption indexes and working capital decisions, as well as the reaction of managers to the level of corruption in their working capital strategies. Furthermore, this study provides theoretical guidelines for regulators and policy makers in dynamic business situations, by investigating of cross-country determinants of working capital management.

This paper is built up upon our preliminary study (Mansoori and Muhammad, 2015). The main differences are summarized as follows: 1) time- period of the study is updated to 12 years from 2005 to 2017. 2) Country and industry's dummies are applied to the models to control the effects of the heterogeneity of countries and industries. 3) Wald test was performed as a robustness test to examine if the addition of corruption indexes to the models has significantly improved the explanatory power of the models

\section{LITERATURE REVIEW}

By searching through the literature on determining factors of working capital management, the factors can be divided into two groups: internal factors related to firm-specific characters that fall under the management's control, and external factors which are out of the management's control.

A recent study by Zariyawati et al., (2010) used CCC as a comprehensive indicator for working capital management as dependent variable with five firm-specific variables including firm size, debt ratio, 
sales growth, number of board directors, and fraction of outsiders on the board directors, as well as two macroeconomic variables, GDP and consumer price index (CPI) as external factors, as explanatory variables. The results showed that greater firms are more efficient than smaller firms with regard to working capital management; Firms with more debts have less working capital as the cost of external financing is higher for these firms; Firms expand their investment on working capital during the economic boom as indicated by the positive relationship between economic growth and working capital; A negative relationship between $\mathrm{CCC}$ and sales growth was found, indicating that corporations use short-term financing to supply future demands. However, the study found no evidence for the effect of corporate governance variables on working capital management. On the external factors, the study found that the volume of working capital decreases as the inflation rate increases.

Gill (2011) focused on Canadian companies to identify the factors that affect working capital management. The sample included 166 Canadian companies listed on the Toronto Stock Exchange from 2008 to 2010. The ratio of Working Capital Requirement (WCR) to total assets was used as the dependent variable and as a proxy for working capital management. Several explanatory variables including operation cycle, operation cash flow to total assets ratio, sales growth, ROA, Tobin's q, debt ratio, and firm size were utilized to explain the working capital management. By applying the panel data analysis, the study showed that WCR was positively correlated with operation cycle, firm return on assets, and industry and internationalization dummies. In addition, WCR was negatively correlated to firm size and Tobin's q. the study found no significant relationship between WCR and debt ratio.

Mansoori and Muhammad (2012) examined working capital management in Singapore firms. The sample included 94 firms in seven different sectors. CCC was used as a comprehensive measure for working capital management, and both internal and external variables were deployed in the model to determine CCC. The result of panel data analysis indicated that firm size, operation cash flow, and GDP has effected the length of CCC negatively.

A number of other studies (e.g., see Cohen and Li, 2013; Chen et al., 2014; Caprio et al., 2013) have investigated the effect of government quality on working capital management, most of which focused on the role of government in liquid working capital.

Cohen and Li (2013) examined the role of the U.S. Government on the amount of firms' cash holdings. The researchers collected a data sample including 9,437 U.S. firms for 1976 to 2011 period. The results of panel data analysis showed that firms that have the U.S. Government as a major customer held less cash and cash equivalent because these firms received lower trade credits from suppliers and more repatriation taxes.

Chen et al., (2014) investigated the effect of government quality on the cash holding of firms. The researchers argued that firms hold less cash to avoid resource extraction by bad governments. By contrast, "a good government refrains from expropriating firms and enables firms to hold more cash". The research sample included 3,074 Chinese firms from 2005 to 2007. Four government quality indicators were used including property rights index, confidence in courts index, corruption index, and government efficiency index. The government quality indicators are obtained from World Bank survey for 120 Cities in China. The result of the panel data analysis showed that a good government reduces firms' financial constraints by facilitating the firms' access to bank loans and trade credits and by attracting more foreign direct investment (FDI) into the region. Moreover, the researchers found evidence that supports Stulz's (2005) argument on the interaction between the twin agency problems.

Caprio et al. (2013) investigated the relationship between the risk of government extractions and the structure of firms' assets holding. The researchers argued that in countries where government expropriations are higher, firms hold a lower fraction of their assets in liquid form. On the contrary, the researchers believed that managers increase the level of investment in properties, plants, equipment, and inventories as the risk of expropriation by the government increases. The empirical test was based on cross-sectional regressions for 2005, covering 30000 firms across 109 countries. The ratio of cash to marketable securities was used as the dependent variable. The likelihood of government extraction that was measured by control of corruption index was used as one explanatory variable. The results of the panel data analysis indicated that corporate holdings of liquid assets are negatively correlated to the 
control of corruption index, confirming the argument that managers channel the liquid assets of firms into fixed assets to shield assets form extraction by governments.

\section{RESEARCH METHODOLOGY}

\section{Sample Selection}

A large data set that covers data from 2005 to 2017 from five ASEAN countries, namely, Malaysia, Indonesia, Singapore, Thailand, and the Philippines, was used to investigate how the level of corruption in these countries affect working capital management.

\section{TABLE 1 SAMPLE SELECTION OF EACH COUNTRY}

\begin{tabular}{lc}
\hline Country & No. of selected firms \\
\hline Malaysia & 165 \\
Singapore & 113 \\
Indonesia & 112 \\
Thailand & 109 \\
Philippines & 34 \\
\hline
\end{tabular}

Table 1 summarizes the number of firms chosen for each individual country of our sample processes for the selection of each sample country. In choosing firms, first, the population of all active firms that were listed on the stock markets' main board from 2005 to 2017 was determined. Second, the firms that were active in financial, insurance, and mutual fund sectors were excluded from the sample, following the previous studies on working capital of Caballero et al., (2009), Chiou and Cheng (2006), Mansoori and Mansoori (2016). Finally, only those firms with complete data on working capital management indicators were included in the sample. The final sample comprised of 533 firms. The proportion of Malaysian firms in the sample was the largest (165 firms out of 533), whereas the proportion of Philippine firms was the lowest (34 firms). The other members of ASEAN, including Brunei, Myanmar, Cambodia, Laos, and Vietnam, were excluded from the sample because they did not have complete data throughout the study.

\section{Data and Variable Measurement}

Two dependent variables, and eight explanatory variables were used for investigating the effect of corruption indicators on working capital management. The indicators suggested by Shulman and Cox (1985) as well as by Richards and Laughlin (1980) were selected as measures of working capital management, namely, net liquid balance (NLB) and cash conversion cycle (CCC). These indicators have been used by many researchers as comprehensive measures of working capital management (e.g., see Caballero et al., 2008; Chiou and Cheng, 2006; Mansoori and Muhammad, 2012)

The amount of available liquid resources for financing the working capital requirements of a firm is represented by NLB. Given that NLB does not include operation cycle items such as inventories and account receivables, a higher level of NLB indicates a greater financial flexibility to satisfy a firm's working capital requirement. NLB is equal to the sum of cash and cash equivalents and short-term investments subtracted by short-term debts. NLB is deflated by total assets.

Cash Conversion Cycle (CCC) is defined as the time between the cash outlay for the creation of a product and the collection of account receivables from the sales of the same product. The CCC is calculated as the sum of receivables collection period (RCP) and inventory conversion period (ICP) subtracted by payment deferral period (PDP). ICP refers to the number of days during which raw material must be converted into finished goods. This component is given by the average inventory multiplied by 365 and divided by the cost of the sold goods. RCP indicates the number of days for the firm to collect receivables, which is computed as the average accounts receivable multiplied by 365 and then divided by 
the annual sales. The sum of ICP and RCP is called the operation cycle. Finally, PDP indicates the number of days for the firm to pay the account payables to the supplier credits. This component is calculated as the average account payables multiplied by 365 and divided by the cost of sold goods.

\section{SUMMARY OF RESEARCH VARIABLES}

\begin{tabular}{|c|c|}
\hline Variables & Methods for Measurement \\
\hline Net Liquid Balance (NLB) & $\begin{array}{l}\text { Cash and cash equivalents }+ \text { Short-term investment }- \text { Short-term } \\
\text { debts/Total assets }\end{array}$ \\
\hline Cash Conversion Cycle (CCC) & $\begin{array}{l}\text { Accounts receivable period }+ \text { Inventory conversion period - } \\
\text { Accounts payable period }\end{array}$ \\
\hline Control of Corruption Index (CCI) & Available on http://www.govindicators.org/ \\
\hline Corruption Perception Index (CPI) & Available on http://www.transparency.org/ \\
\hline Firm Size (Size) & Natural logarithm of total assets (U.S Dollars) \\
\hline Cash Flow (Cflow) & Operating cash flow/Total sales $* 100$ \\
\hline Growth Opportunities (SG) & $\begin{array}{l}\text { Sales during the current year-Sales during the } \\
\text { Previous year/ Sales during the previous year }\end{array}$ \\
\hline Profitability (ROA) & Net profit/Total assets (ROA) \\
\hline Capital Expenditures (CEXP) & Total fixed assets acquired + Capital expenses/Total sales \\
\hline Leverage (LEV) & (Total debts/ total assets) \\
\hline Industry Effects & $\begin{array}{l}\text { Dummy variables, which take the value of } 1 \text { for } \\
\text { each industry and } 0 \text { for others }\end{array}$ \\
\hline
\end{tabular}

Table 2 summarizes the research variables. Explanatory variables include corruption indexes that refer to the extent of private gains exercised by public power, including both basic and petty forms of corruption. In addition, the index captures the power of the state to obtain special and extra interests (Kaufmann et al., 2012). In this study, two corruption indexes have been applied to investigate the effect of corruption on working capital management. The first index is Control of Corruption $(C C)$, which has been issued by the World Bank Institute since 1996 in their project, "The Worldwide Governance Indicators (WGIs): Methodology and Analytical Issues.". CC is related to the perception of public power to detect both petty and grand forms of corruption by the private sector. Several concepts were used to measure $C C$, such as the frequency of extra payments by corporations when making trade permit applications, frequency of extra public utility payments by corporations, frequency of extra tax payments by corporations, and frequency of extra loan application payments from corporations (Kaufmann et al., 2012). The CC index were reported in either percentile ranking ranging from zero (lowest value) to hundred (highest value) or in standard normal units ranging from -2.5 to 2.5 (World Bank, 2017). The present study uses percentile ranking given that high scores in this range indicate a lower corruption for a specific country. The second corruption index is Corruption Perception Index (CPI) that has been issued by Transparency International. The CPI scores and ranks countries based on how corrupt a country's public sector is perceived to be. It is a composite index, a combination of surveys and assessments of corruption, collected by a variety of reputable institutions. The CPI is the most widely used indicator of corruption worldwide. A country CPI's score indicates the perceived level of public sector corruption on a scale of $0-100$, where 0 means that a country is perceived as highly corrupt and a 100 means that a country is perceived as very clean.

The use of the corruption indexes (CC and CPI) has several advantages. First, the indexes tend to have smaller measurement errors as they are compiled from several independent data sources including 
that non-governmental organizations, commercial business providers, surveys, and expert assessments. Second, the indexes can be compared across different countries and periods given that they share common scale across countries. Third, these indicators are updated annually. Fourth, the indexes are available for the selected countries (Kaufmann et al., 2012). Finally, several control variables were chosen from past studies in consideration of the determinants of working capital management. These variables are leverage, firm size, sales growth, operation cash flow, return on assets and capital expenditures.

\section{Descriptive Statistics}

Table 3 lists the descriptive statistics of the dependent and independent variables.

TABLE 3

DESCRIPTIVE STATISTICS FOR THE ENTIRE SAMPLE FROM 2005 TO 2017

\begin{tabular}{lrrrrr}
\hline & \multicolumn{1}{c}{ Mean } & Median & \multicolumn{1}{l}{ Max } & \multicolumn{1}{l}{ Min } & \multicolumn{1}{c}{ SD } \\
\hline CCC & 106.084 & 97.452 & 361.917 & -96.424 & 69.022 \\
NLB & -0.213 & -0.199 & 0.962 & -3.186 & 0.289 \\
LEV & 0.237 & 0.202 & 1.274 & 0.000 & 0.205 \\
GROWTH & 0.128 & 0.084 & 3.489 & -0.996 & 0.292 \\
CFLOW & 0.092 & 0.081 & 0.968 & -0.986 & 0.115 \\
ROA & 0.058 & 0.056 & 0.590 & -0.576 & 0.085 \\
CEXP & 0.057 & 0.034 & 0.553 & 0.000 & 0.073 \\
LNSIZE & 15.016 & 14.028 & 24.925 & 8.201 & 3.477 \\
CPI & 4.852 & 4.40 & 9.40 & 1.90 & 2.523 \\
CCI & 58.065 & 58.100 & 99.00 & 10.200 & 26.213 \\
\hline
\end{tabular}

As it can be seen in Table 3, the average CCC among the sample countries is approximately 106 days with a median and average standard deviation of 97 and 69 days, respectively. This means that, on average, sample firms wait 106 days to convert their products to cash. Positive CCC implies that the firms should finance their operations for 106 days until their products are converted to cash. The average NLB among the sample countries is approximately -0.2 , meaning that the sum of cash and cash equivalents of the sample firms are less than short term debts. A negative value of NLB suggests that sample firms are dependent on external financing to satisfy their working capital requirements (Shulman and Cox, 1985). 
TABLE 4

DESCRIPTIVE STATISTICS FOR EACH COUNTRY FROM 2005 TO 2017

\begin{tabular}{||ccccc|c||} 
Thailand & Philippines & Singapore & Indonesia & Malaysia & \\
$\mathrm{M}$ & $\mathrm{M}$ & $\mathrm{M}$ & $\mathrm{M}$ & $\mathrm{M}$ & \\
$(\mathrm{SD})$ & $(\mathrm{SD})$ & $(\mathrm{SD})$ & $(\mathrm{SD})$ & $(\mathrm{SD})$ & \\
\hline 97.51 & 107.14 & 100.92 & 97.91 & 118.55 & \\
$(65.43)$ & $(69.55)$ & $(67.04)$ & $(70.84)$ & $(69.28)$ & CCC \\
-0.22 & -0.18 & -0.19 & -0.26 & -0.18 & \\
$(0.23)$ & $(0.30)$ & $(0.28)$ & $(0.35)$ & $(0.26)$ & NLB \\
0.25 & 0.19 & 0.19 & 0.29 & 0.23 & LEV \\
$(0.21)$ & $(0.20)$ & $(0.16)$ & $(0.25)$ & $(0.18)$ & \\
0.11 & 0.14 & 0.13 & 0.15 & 0.12 & GROWTH \\
$(0.22)$ & $(0.27)$ & $(0.36)$ & 0.29 & $(0.28)$ & \\
0.12 & 0.08 & 0.08 & 0.07 & 0.10 & CFLOW \\
$(0.11)$ & $(0.11)$ & $(0.11)$ & $(0.13)$ & $(0.11)$ & \\
0.08 & 0.05 & 0.04 & 0.07 & 0.05 & ROA \\
$(0.07)$ & $(0.07)$ & $(0.10)$ & 0.10 & $(0.07)$ & \\
0.06 & 0.05 & 0.05 & 0.05 & 0.06 & CEXP \\
$(0.08)$ & $(0.07)$ & $(0.07)$ & $(0.07)$ & $(0.08)$ & \\
15.32 & 15.93 & 12.27 & 20.60 & 12.71 & LNSIZE \\
$(1.53)$ & $(1.78)$ & $(1.52)$ & $(1.57)$ & $(1.30)$ & \\
3.466 & 2.47 & 9.311 & 2.322 & 4.922 & CPI \\
$(0.18)$ & $(0.09)$ & $(0.07)$ & $(0.35)$ & $(0.28)$ & \\
49.13 & 32.40 & 98.39 & 23.63 & 65.01 & CCI \\
$(3.15)$ & $(6.45)$ & $(0.38)$ & $(7.34)$ & $(3.53)$ & \\
& & & & &
\end{tabular}

Table 4 presents the descriptive statistics of each individual country over the period from 2005 to 2017. On average, Malaysian firms have longer CCC at 118 days, compared to other sample ASEAN countries. This finding implies that Malaysian managers prefer more conservative working capital strategies than their counterparts in other selected countries.

On the other hand, Indonesian firms have a higher negative value of $N L B(-0.26)$, indicating a higher degree of dependence on external financing for working capital requirements. Indonesian firms have the highest leverage ratio and sales growth ratio, while Thai firms have the highest $C F L O W$ to sales and the highest return on asset ratios. About $6 \%$ of the sales income of Malaysian and Thai firms was tied up in $C E X P$, whereas the rate is 0.05 for other countries. Indonesian firms have more assets compared to the other countries, as the mean of the natural $\log$ of the Indonesian firms' assets is 20.6. On corruption index, Singapore have the lower corruption indexes and the lowest standard deviation in corruption indexes (indicating more stability in controlling corruption) compared with other sample countries.

\section{Model Specifications}

Four models have been deployed to investigate the impact of corruption on working capital management. The first and second models investigate the relationship between CCC and corruption indexes, while the third and fourth models examine the impact of corruption indexes on NLB. The models are as follows:

Model 1) CCC $=\beta_{0}+\beta_{1} \mathrm{CC}+\beta_{2}$ SIZE $+\beta_{3} \mathrm{LEV}+\beta_{4} \mathrm{SG}+$

$\beta_{5}$ Cflow $+\beta_{6}$ CEXP $+\beta_{7}$ ROA + Industry Dummy $+€$ 
Model 2) CCC $=\beta_{0}+\beta_{1}$ CPI $+\beta_{2}$ SIZE $+\beta_{3} \mathrm{LEV}+\beta_{4} \mathrm{SG}+$

$\beta_{5}$ Cflow $+\beta_{6}$ CEXP $+\beta_{7}$ ROA + Industry Dummy $+€$

Model 3) NLB $=\beta_{0}+\beta_{1} C C+\beta_{2}$ SIZE $+\beta_{3}$ LEV $+\beta_{4}$ SG +

$\beta_{5}$ Cflow $+\beta_{6}$ CEXP $+\beta_{7}$ ROA + Industry Dummy $+€$

Model 4) NLB $=\beta_{0}+\beta_{1}$ CPI $+\beta_{2}$ SIZE $+\beta_{3}$ LEV $+\beta_{4}$ SG +

$\beta_{5}$ Cflow $+\beta_{6}$ CEXP $+\beta_{7}$ ROA + Industry Dummy $+€$

The variables notations are: cash conversion cycle (CCC), net liquid balance (NLB), leverage (LEV), firm size (LNSIZE), growth opportunity (GROWTH), profitability (ROA), operation cash flow (CFLOW), capital expenditures (CEXP), control of corruption index (CCI), and corruption perception index (CPI). The industry dummies were included to capture the unobserved industry-specific effects.

Panel data analysis was used on four models. A balanced panel data is a panel that includes data for all years, cross-sections, and sample firms (Gujarati, 2003). Similar to most studies, the present study applied a balanced panel data set on the determinants of working capital management (e.g., see Caballero et al., 2009; Mansoori and Muhammad, 2012).

\section{RESULTS AND DISCUSSION}

\section{Correlation Analysis}

The correlation matrix was used to test whether high multicollinearity exists among the explanatory variables. Multicollinearity refers to the high correlation between the independent variables in the multiple regression models that is caused by the lack of interdependence among the independent variables (Anren, 2007).

TABLE 5

\section{CORRELATION MATRIX OF INDEPENDENT VARIABLES}

\begin{tabular}{|c|c|c|c|c|c|c|c|c|}
\hline 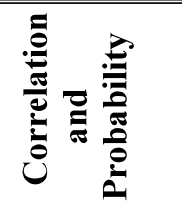 & $\underset{x}{\partial}$ & $\frac{\beta}{2}$ & 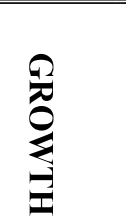 & 㒸 & $\begin{array}{l}\pi \\
0\end{array}$ & $\underset{\mathbf{N}}{\mathscr{N}}$ & $\Omega$ & $\hat{\Omega}$ \\
\hline CEXP & 1.00 & & & & & & & \\
\hline CFLOW & $\begin{array}{c}0.31 \\
(0.000)\end{array}$ & 1.00 & & & & & & \\
\hline GROWTH & $\begin{array}{c}0.01 \\
(0.430)\end{array}$ & $\begin{array}{c}0.03 \\
(0.020)\end{array}$ & 1.00 & & & & & \\
\hline LEV & $\begin{array}{c}0.06 \\
(0.000)\end{array}$ & $\begin{array}{l}-0.21 \\
(0.000)\end{array}$ & $\begin{array}{c}0.02 \\
(0.120)\end{array}$ & 1.00 & & & & \\
\hline ROA & $\begin{array}{c}0.05 \\
(0.000)\end{array}$ & $\begin{array}{c}0.48 \\
(0.000)\end{array}$ & $\begin{array}{c}0.12 \\
(0.000)\end{array}$ & $\begin{array}{c}-0.21 \\
(0.000)\end{array}$ & 1.00 & & & \\
\hline SIZE & $\begin{array}{c}0.02 \\
(0.16)\end{array}$ & $\begin{array}{c}0.02 \\
(0.17)\end{array}$ & $\begin{array}{c}0.06 \\
(0.000)\end{array}$ & $\begin{array}{c}0.06 \\
(0.000)\end{array}$ & $\begin{array}{c}0.08 \\
(0.000)\end{array}$ & $\begin{array}{l}1.00 \\
----\end{array}$ & & \\
\hline CPI & $\begin{array}{c}0.05 \\
(0.000)\end{array}$ & $\begin{array}{c}0.06 \\
(0.000)\end{array}$ & $\begin{array}{c}-0.05 \\
(0.000)\end{array}$ & $\begin{array}{c}-0.09 \\
(0.000)\end{array}$ & $\begin{array}{c}-0.07 \\
(0.000)\end{array}$ & $\begin{array}{c}-0.79 \\
(0.00)\end{array}$ & 1.00 & \\
\hline CCI & $\begin{array}{c}0.03 \\
(0.040)\end{array}$ & $\begin{array}{c}0.06 \\
(0.000)\end{array}$ & $\begin{array}{c}-0.03 \\
(0.070)\end{array}$ & $\begin{array}{c}-0.15 \\
(0.000)\end{array}$ & $\begin{array}{l}-0.08 \\
(0.000)\end{array}$ & $\begin{array}{c}-0.22 \\
(0.000)\end{array}$ & $\begin{array}{c}0.97 \\
(0.000)\end{array}$ & $\begin{array}{l}1.00 \\
----\end{array}$ \\
\hline
\end{tabular}

Table 5 shows the result of correlation analysis based on Spearman correlation matrix. The results indicate that no strong multicollinearity exists among the independent variables. The highest correlation among the control variables was found between ROA and CFLOW (at 0.48), indicating that no serious 
collinearity problem is present. High correlation among the corruption indexes stemmed from the fact that the sources have accurately measured corruption despite using different methodologies.

\section{Regression Analysis}

The present study hypothesized the existence of a linear relationship between the independent variables and $C C C$, on the one hand, and NLB, on the other, as two measures of working capital management.

The Chow test (redundant fixed effect) was selected to test the poolability of the data, as recommended by Gujarati (2003). The Chow test strongly rejected the null hypothesis of the restricted model with a single intercept. Evidently, the test demonstrates that the pooled data could not be used to investigate the impact of corruption indexes on working capital management. Consequently, the panel data models with FE and RE effect estimations were selected. The Hausman test, developed by Hausman (1978), was used to select between the FE and the RE models. The Hausman test statistic and associated $p$-values strongly rejected the null hypothesis of no correlation between the individual effects and repressors. Hence, the FE was selected for all the models rather than the RE.

TABLE 6

RESULT OF REGRESSION ANALYSIS FOR THE FIRST AND SECOND MODELS

\section{Dependent Variable: CCC}

Sample (adjusted): 2005-2017

Periods included: 13

Cross-sections included: 533

Total panel (balanced) observations: 6929

\begin{tabular}{|c|c|c|c|c|}
\hline $\begin{array}{c}\text { Independent } \\
\text { Variables }\end{array}$ & Pooled OLS & Fixed Effect & Pooled OLS & Fixed Effect \\
\hline LEV & $\begin{array}{c}39.458 \\
(0.000)^{*}\end{array}$ & $\begin{array}{c}38.279 \\
(0.000)^{*}\end{array}$ & $\begin{array}{c}38.417 \\
(0.000)^{*}\end{array}$ & $\begin{array}{c}37.422 \\
(0.000)^{*}\end{array}$ \\
\hline GROWTH & $\begin{array}{c}4.816 \\
(0.001)^{*}\end{array}$ & $\begin{array}{l}-0.784 \\
(0.468)\end{array}$ & $\begin{array}{c}4.571 \\
(0.002)^{*}\end{array}$ & $\begin{array}{l}-0.707 \\
(0.511)\end{array}$ \\
\hline CFLOW & $\begin{array}{l}-16.026 \\
(0.046)^{*}\end{array}$ & $\begin{array}{l}-28.940 \\
(0.000)^{*}\end{array}$ & $\begin{array}{l}-16.362 \\
(0.041)^{*}\end{array}$ & $\begin{array}{l}-29.439 \\
(0.000)^{*}\end{array}$ \\
\hline ROA & $\begin{array}{l}-21.214 \\
(0.006)^{*}\end{array}$ & $\begin{array}{l}-35.367 \\
(0.000)^{*}\end{array}$ & $\begin{array}{l}-21.114 \\
(0.006)^{*}\end{array}$ & $\begin{array}{l}-35.499 \\
(0.000)^{*}\end{array}$ \\
\hline CEXP & $\begin{array}{l}-18.807 \\
(0.034)^{*}\end{array}$ & $\begin{array}{l}-16.667 \\
(0.005)^{*}\end{array}$ & $\begin{array}{l}-18.755 \\
(0.034)^{*}\end{array}$ & $\begin{array}{l}-17.741 \\
(0.003)^{*}\end{array}$ \\
\hline LNSIZE & $\begin{array}{c}-7.265 \\
(0.000)^{*}\end{array}$ & $\begin{array}{c}4.945 \\
(0.000)^{*}\end{array}$ & $\begin{array}{c}-6.419 \\
(0.000)^{*}\end{array}$ & $\begin{array}{c}5.375 \\
(0.000)^{*}\end{array}$ \\
\hline CPI & $\begin{array}{c}6.337 \\
(0.000)^{*}\end{array}$ & $\begin{array}{c}1.274 \\
(0.019)^{*}\end{array}$ & & \\
\hline $\mathrm{CCI}$ & & & $\begin{array}{c}0.366 \\
(0.000)^{*}\end{array}$ & $\begin{array}{c}4.491 \\
(0.001)^{*}\end{array}$ \\
\hline Constant & $\begin{array}{l}238.867 \\
(0.000)^{*}\end{array}$ & $\begin{array}{c}34.732 \\
(0.008)^{*}\end{array}$ & $\begin{array}{l}216.433 \\
(0.000)^{*}\end{array}$ & $\begin{array}{c}40.056 \\
(0.002)^{*}\end{array}$ \\
\hline $\mathrm{R}^{2}$ & 0.749 & 0.938 & 0.748 & 0.938 \\
\hline Durbin- & 2.316 & 1.94 & 2.323 & 1.94 \\
\hline
\end{tabular}




\begin{tabular}{|c|c|c|c|c|}
\hline $\begin{array}{c}\text { Watson } \\
\text { Chow Test }\end{array}$ & $\begin{array}{c}105.870 \\
(0.000)^{*}\end{array}$ & $\begin{array}{c}103.939 \\
(0.000)^{*}\end{array}$ & \\
\hline $\begin{array}{c}\text { Hausman } \\
\text { Test }\end{array}$ & & $\begin{array}{c}51.682 \\
(0.000)^{*}\end{array}$ & & 59.978 \\
\end{tabular}

Note: $C C C=$ Cash Conversion Cycle; $C C I=$ Control of Corruption Index; $C P I=$ Corruption Perception Index; CEXP = the ratio of capital expenditures to sales; CFLOW = operation cash flow to sales; GROWTH $=\left(\right.$ sales $_{1}-$ sales $_{0}$ sales $\left.)_{0}\right) ; L E V=$ total debt to total assets ratio; $L N S I Z E=$ natural logarithm of total assets; ROA = return on assets ratio; * indicates a significance level at 1\%; ** indicates a significance level at 5\%; *** indicates significance level at $10 \%$

Table 6 shows the result of regression analysis for the first and second models. The result revealed that the null hypothesis, which stated that no significant relationship exists between $C C I, C P I$ and $C C C$, was rejected at the significance level of $5 \%$. In other words, according to the results, $C C I$, and $C P I$ have positively affected $C C C$; that is, managers increase their investment in working capital and the length of $C C C$ when the level of corruption is more controlled by the government. Firms can increase the length of $C C C$ in two ways. First by increasing the level of investment in the operation cycle through increasing the amount of account receivables and inventories. Second by using the external sources, other than the supplier credits, to finance the operation cycle.

Both of these approaches that increase the length of $C C C$ could be affected by the $C C I$ and $C P I$ for several reasons. First, corruption may be one of the obstacles that restrict the access of firms to the external financing, especially from banks (Beck et al., 2005). Therefore, the CCI and CPI can help firms to have better access to external financing. Such improved access encourages managers to increase the level of their investment in account receivables and inventories (Caballero et al., 2009; Chiou and Cheng, 2006; Fazzari and Peterson, 1993).

The second reason is the fact that corruption may change the policies on investment. As Caprio et al., (2013) empirically showed that the level of investment in fixed assets increases with the increase of the level of corruption. Moreover, they determined that firms hold a lower fraction of assets in cash when the level of corruption is high because liquid assets are easier to extract than the fixed ones, such as property, plant, equipment, and inventories. Consequently, the $C C I$ and $C P I$ encourage the managers to increase the level of their investment in current assets, including account receivables and inventories.

The third reason is the case that corruption reduces growth rate, human capital, and the share of private capital, as empirically discovered by Hung (2001). Therefore, the CCI leads to more economic growth and extended sharing of private capital. Also, the level of investment flows and cost of capital can be affected by corruption (Pankajk et al., 2012). All these or their interactions may explain the positive relationship between the $C C I$ and $C C C$. These results are consistent with Chen et al. (2014) have argued that firms in more corrupt countries have to utilize more resources to access external financing, especially from the governmental banks, and therefore, increasing the cost of capital. Hence, the CCI could reduce the cost of capital and subsequently increase the level of investment in the operation cycle and the length of $C C C$. 
TABLE 7

RESULT OF REGRESSION ANALYSIS FOR THIRD AND FOURTH MODELS

\begin{tabular}{|c|c|c|c|c|}
\hline \multicolumn{5}{|c|}{$\begin{array}{l}\text { Dependent Variable: NLB } \\
\text { Sample (adjusted): } 2005-2017 \\
\text { Periods included: } 13 \\
\text { Cross-sections included: } 533 \\
\text { Total panel (balanced) observations: } 6929 \\
\end{array}$} \\
\hline $\begin{array}{c}\text { Independent } \\
\text { Variables }\end{array}$ & Pooled OLS & Fixed Effect & Pooled OLS & Fixed Effect \\
\hline LEV & $\begin{array}{c}-0.46 \\
(0.000)^{*}\end{array}$ & $\begin{array}{c}-0.42 \\
(0.000)^{*}\end{array}$ & $\begin{array}{c}-0.43 \\
(0.000)^{*}\end{array}$ & $\begin{array}{c}-0.042 \\
(0.000)^{*}\end{array}$ \\
\hline GROWTH & $\begin{array}{l}0.000 \\
(0.94)\end{array}$ & $\begin{array}{l}0.000 \\
(0.68)\end{array}$ & $\begin{array}{l}-.0 .01 \\
(0.23)\end{array}$ & $\begin{array}{l}0.000 \\
(0.94)\end{array}$ \\
\hline CFLOW & $\begin{array}{c}0.14 \\
(0.000)^{*}\end{array}$ & $\begin{array}{c}0.14 \\
(0.000)^{*}\end{array}$ & $\begin{array}{c}0.24 \\
(0.000)^{*}\end{array}$ & $\begin{array}{c}0.14 \\
(0.000)^{*}\end{array}$ \\
\hline ROA & $\begin{array}{c}0.08 \\
(0.000)^{*}\end{array}$ & $\begin{array}{c}0.09 \\
(0.000)^{*}\end{array}$ & $\begin{array}{c}-0.05 \\
(0.015)^{*}\end{array}$ & $\begin{array}{c}0.08 \\
(0.000)^{*}\end{array}$ \\
\hline CEXP & $\begin{array}{l}-.010 \\
(0.58)\end{array}$ & $\begin{array}{c}0.01 \\
(0.78) \\
\end{array}$ & $\begin{array}{l}-0.04 \\
(0.29)\end{array}$ & $\begin{array}{l}0.000 \\
(0.94)\end{array}$ \\
\hline LNSIZE & $\begin{array}{l}0.000 \\
(0.21) \\
\end{array}$ & $\begin{array}{c}-0.02 \\
(0.02)^{*}\end{array}$ & $\begin{array}{c}0.01 \\
(0.008)^{*}\end{array}$ & $\begin{array}{c}-0.02 \\
(0.020)^{*}\end{array}$ \\
\hline CPI & $\begin{array}{c}-0.03 \\
(0.007)^{*}\end{array}$ & $\begin{array}{c}-0.09 \\
(0.000)^{*}\end{array}$ & & \\
\hline CCI & & & $\begin{array}{c}-0.04 \\
(0.050)^{*}\end{array}$ & $\begin{array}{c}-0.02 \\
(0.006)^{*}\end{array}$ \\
\hline Constant & $\begin{array}{c}-0.02 \\
(0.000)^{*}\end{array}$ & $\begin{array}{c}0.28 \\
(0.020)^{*}\end{array}$ & $\begin{array}{c}-0.41 \\
(0.000)^{*}\end{array}$ & $\begin{array}{c}0.24 \\
(0.006)^{*}\end{array}$ \\
\hline $\mathrm{R}^{2}$ & 0.87 & 0.93 & 0.74 & 0.93 \\
\hline Durbin- Watson & 2.01 & 1.913 & 2.05 & 1.911 \\
\hline Chow Test & $\begin{array}{c}3.354 \\
(0.000)^{*}\end{array}$ & & $\begin{array}{c}3.329 \\
(0.000)^{*}\end{array}$ & \\
\hline Hausman Test & & $\begin{array}{c}88.197 \\
(0.000)^{*}\end{array}$ & & $\begin{array}{c}88.338 \\
(0.000)^{*}\end{array}$ \\
\hline
\end{tabular}

Note: $N L B=$ Net Liquid Balance; $C C I=$ Control of Corruption Index; $C P I=$ Corruption Perception Index; CEXP = the ratio of capital expenditures to sales; $C F L O W=$ operation cash flow to sales; GROWTH $=$ (sales s $_{1}$ - sales ${ }_{0}$ sales $)_{0}$; $L E V=$ total debt to total assets ratio; $L N S I Z E=$ natural logarithm of total assets; ROA = return on assets ratio; * indicates a significance level at $5 \%$;

Table 7 shows the result of regression analysis for the third and fourth models where $N L B$ was used as dependent variable. The results of the regression models demonstrate that the $C P I$ and $C C I$ have negative and significant effect on the $N L B$ at the significance level of $5 \%$. The negative relationship between the corruption indexes and $N L B$ specifies that when corruption increases, the managers reduce the amount of liquid working capital. The results are consistent with the previous studies has done by Bates et al. (2009) and Dittmar and Smith (2007) who believe that firms hold less cash and cash equivalents to protect himself against the risk of expropriation by state rulers.

In interpreting these results, Bates et al. (2009) believed that firms hold cash and cash equivalents for potential negative shocks, particularly when firms have higher external financing cost. Moreover, they argued that firms hold less cash when they have better access to capital markets because they can afford to lower their investment in the liquid working capital. Agency problems have also been mentioned as 
one of the reasons for the lower investment in the liquid working capital. Dittmar and Smith (2007) showed that firms which are situated in countries with greater agency problems have lower investment in the liquid working capital.

All the above reasons can justify the negative relationship between the corruption indexes and $N L B$, in which the high level of corruption increase the transaction cost (Liu et al., 2008), restrict firms' access to external financing (La Porta et al., 1998; Liu et al., 2008), resonate firms financial constrains (Zhu and Chen, 2006) and increase the agency problems and information asymmetry of firms (Stulz, 2005). Consequently, the high level of corruption indexes encourages managers to decrease the amount of investment in the liquid working capital.

\section{ROBUSTNESS TESTS}

Apart from the main models presented in Tables 6 and 7, several robustness tests were applied to investigate the influence of the corruption indicators on working capital management. These analyses include applying industry dummies to the main models, adding country dummies to the main models, and conducting the Wald test. Robustness analysis was performed in this study for two reasons: to explain some of the differences between the results of this research and those found in previous studies; second, the analysis could be made more robust through the introduction of industry and country dummies.

\section{Industry Dummies}

The main purpose of applying the industry dummies to the main models is to control the effect of different industries on working capital management that cannot be captured through other explanatory variables. These industries are not homogenous because of the heterogeneity in technology, trade credits, rate of innovations, and so on (Greg and Krueger, 2005; Niskanen and Niskanen, 2006; Weinraub and Visscher, 1998).

TABLE 8

\section{LIST OF INDUSTRIES AND THE NUMBER OF FIRMS IN EACH INDUSTRY}

\begin{tabular}{|l|l|}
\hline Industry & Number of Firms \\
\hline Automobile and Parts & 18 \\
\hline Chemical & 32 \\
\hline Construction and material & 62 \\
\hline Electronic & 45 \\
\hline Food Producers & 72 \\
\hline Forestry and paper & 12 \\
\hline General Industries & 27 \\
\hline General Retailers & 26 \\
\hline Household Goods & 20 \\
\hline Industrial engineering & 32 \\
\hline Personal goods & 18 \\
\hline Technology Hardware & 26 \\
\hline Industrial Metal & 32 \\
\hline
\end{tabular}

The list of industries and the number of firms in each industry are provided in Table 8 . The dummy variable takes the value of " 1 " for each specific industry and " 0 " otherwise. The dummies are included in the model based on the classification of industries in the DataStream database. An industry must contain at least 10 firms to be included in the model. 
TABLE 9

REGRESSION MODELS WITH THE APPLICATION OF INDUSTRY DUMMIES

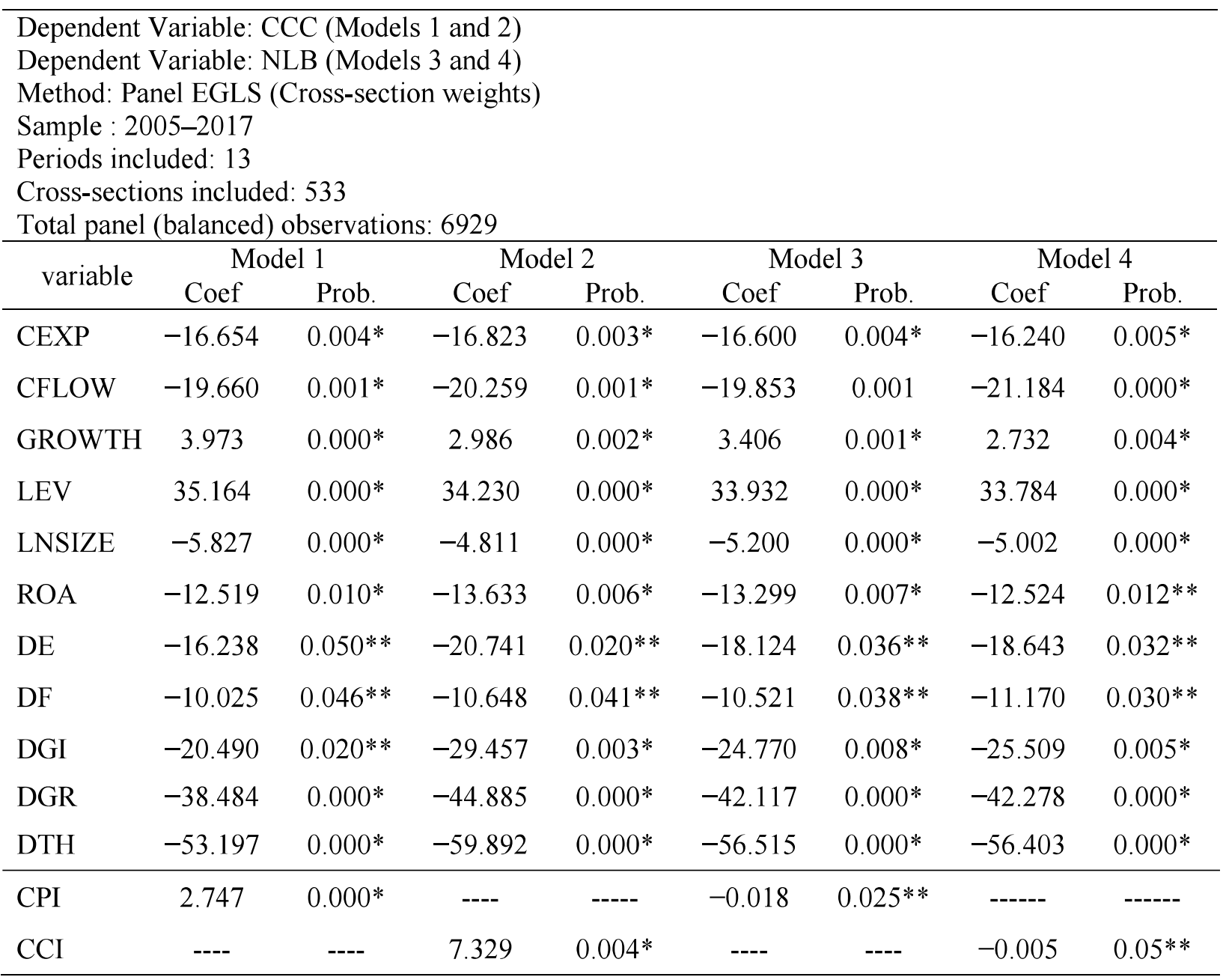

Note. Dependent variable = cash conversion cycle; $C E X P=$ the ratio of capital expenditures to sales; $C F L O W=$ operation cash flow to sales; GROWTH = (sales - sales $_{0} /$ sales $\left._{0}\right)$; LEV = total debt to total assets ratio; LNSIZE = natural logarithm of total assets; ROA = return on assets ratio; $C C I=$ control of corruption index; $C P I=$ Corruption Perception Index; $D E=$ dummy for electronic industries; $D F=$ dummy for food industries; $D G I=$ dummy for general industries; DGR $=$ dummy for general retailer industries; DTH $=$ dummy for technology hardware industries; * indicates a significance level at 1\%; ** indicates a significance level at $5 \%$.

Table 9 show the results of the regression models with including industry dummy variables. The t-test for the dummy parameters in all the models rejected the null hypothesis, which assumed that no difference exists in the intercepts at the significance level of 5\%. Among the 13 industries included in the first and second models (with CCC as dependent variable), five industries had significantly different effects, including "technology hardware", "general retailers", "general industries", "electronic", and "food producers".

Moreover, the result of the application of the industry dummies in the third and fourth models (with NLB as dependent variable) implies that of the 13 industries included in the model, six had significantly different effects than the base industry. The industries with significant effects are "construction and material", "general industries", "electronic", "industrial metal", "household goods", and the "automobile and parts sectors". The negative coefficients of the industry dummies indicate that these industries have aggressive working capital strategies compared with the other industries in the model. Aggressive 
working capital policy refers to maintain the lower amount of working capital elements, which accompanied with high risk of liquidity and high return on working capital investment (Mansoori \& Muhammad, 2012). The results on industry dummies are somehow consistent with those of previous studies (e.g., Mansoori and Muhammad, 2012; Niskanen and Niskanen, 2006; Weinraub and Visscher, 1998), which indicated that working capital strategies vary across industries. The variation in trade credit could account for the differences in the working capital strategies among different industries. Such variation leads to the differences in the amount of account receivables and payables across industries (Niskanen and Niskanen, 2006; Petersen and Rajan, 1997)

\section{Country Dummies}

Country dummy variables were applied to the models primarily to control the effects of the heterogeneity of countries. The countries are not homogenous because of the differences in terms of the extent by which capital markets developed and of the access to external finance, accounting practices, legal systems, geographic size (Beck et al., 2005; Belt and Smith, 1991; La Porta et al., 1997; Maxwell et al., 1998) and their macroeconomic environments.

\section{TABLE 10 \\ REGRESSION MODELS WITH THE APPLICATION OF COUNTRY DUMMIES}

\begin{tabular}{|c|c|c|c|c|c|c|c|c|}
\hline $\begin{array}{l}\text { Dependent } \\
\text { Dependent } \\
\text { Method: Pa } \\
\text { Sample : } 20 \\
\text { Periods incl } \\
\text { Cross-sectic } \\
\text { Total panel }\end{array}$ & $\begin{array}{l}\text { ariable: CC } \\
\text { ariable: NI } \\
\text { 1 EGLS (C } \\
-2017 \\
\text { led: } 13 \\
\text { s included } \\
\text { alanced) }\end{array}$ & $\begin{array}{l}\text { (Models } \\
3 \text { (Models } \\
\text { oss-sectior }\end{array}$ & $\begin{array}{l}\text { and 2) } \\
3 \text { and 4) } \\
\text { weights) }\end{array}$ & & & & & \\
\hline \multirow{2}{*}{ Variable } & \multicolumn{2}{|c|}{ Model 1} & \multicolumn{2}{|c|}{ Model 2} & \multicolumn{2}{|c|}{ Model 3} & \multicolumn{2}{|c|}{ Model 4} \\
\hline & Coef & Prob. & Coef & Prob. & Coef & Prob. & Coef & Prob. \\
\hline CEXP & -14.649 & $0.021 * *$ & -14.966 & $0.010^{*}$ & -14.117 & $0.029 * *$ & -14.268 & $0.029 * *$ \\
\hline CFLOW & -15.241 & $0.024 * *$ & -14.148 & $0.014 * *$ & -15.534 & $0.025 * *$ & -15.341 & $0.033 * *$ \\
\hline GROWTH & 3.891 & $0.000 *$ & 3.257 & $0.001^{*}$ & 3.177 & $0.002 *$ & 2.808 & $0.003 *$ \\
\hline LEV & 38.750 & $0.000 *$ & 39.184 & $0.000 *$ & 38.449 & $0.000 *$ & 38.470 & $0.000 *$ \\
\hline LNSIZE & -10.861 & $0.000 *$ & -10.976 & $0.000 *$ & -10.747 & $0.000 *$ & -10.876 & $0.000 *$ \\
\hline ROA & -11.585 & $0.025^{* *}$ & -13.017 & $0.010^{*}$ & -12.139 & $0.029 * *$ & -11.780 & $0.036 * *$ \\
\hline DIND & 140.965 & $0.000 *$ & 146.572 & $0.000 *$ & 143.104 & $0.000^{*}$ & 145.176 & $0.000 *$ \\
\hline DMAL & 72.861 & $0.000 *$ & 63.969 & $0.000 *$ & 68.148 & $0.000 *$ & 67.330 & $0.000 *$ \\
\hline DPHI & 113.583 & $0.000 *$ & 127.153 & $0.000 *$ & 117.957 & $0.000 *$ & 114.533 & $0.000 *$ \\
\hline DSING & 81.454 & $0.000 *$ & 62.799 & $0.000^{*}$ & 73.486 & $0.000 *$ & 73.050 & $0.000 *$ \\
\hline DTHAI & 93.016 & $0.000 *$ & 99.054 & $0.000 *$ & 96.222 & $0.000 *$ & 97.348 & $0.000 *$ \\
\hline$\overline{\mathrm{CPI}}$ & 2.228 & $0.000 *$ & --- & ---- & -0.006 & $0.027^{*}$ & & \\
\hline $\mathrm{CCI}$ & --- & ---- & 5.029 & $0.036 * *$ & & & -0.001 & $0.075 * * *$ \\
\hline \multicolumn{9}{|c|}{$\begin{array}{l}\text { Note. Dependent variable }=\text { cash conversion cycle; } C E X P=\text { the ratio of capital expenditures to sales; } C F L O W= \\
\text { operation cash flow to sales; GROWTH = }\left(\text { sales }_{1}-\text { sales }_{0} / \mathrm{sales}_{0}\right) ; L E V=\text { total debt to total assets ratio; } L N S I Z E= \\
\text { natural logarithm of total assets; } R O A=\text { return on assets ratio; } C C I=\text { control of corruption index; CPI = Corruption } \\
\text { Perception Index; DIND = dummy variable for Indonesian firms; DMAL = dummy variable for Malaysian firms; } \\
D P H I=\text { dummy variable for Philippines firms; DSIN = dummy variable for Singapore firms; DTHAI = dummy } \\
\text { variable for Thailand firms. * indicates a significant level at } 1 \% \text {; ** indicates a significance level at } 5 \% \text {; *** } \\
\text { indicates a significance level at } 10 \%\end{array}$} \\
\hline
\end{tabular}

Table 10 displays the results of the regression models with the application of country dummy variables. In all the models, the $t$-test of the dummy parameters rejected the null hypothesis, which assumed that no 
difference exists in the intercepts at the significance level of $1 \%$ and $5 \%$. The significant differences in the intercept of each country indicate that the firms of each country in the sample have different working capital strategies, resulting in the varying lengths of $C C C$ and different levels of investment in $N L B$.

\section{Wald Test}

In this study, the Wald test was performed to examine if the addition of corruption indexes to the models has significantly improved the explanatory power of the models.

TABLE 11

RESULTS OF THE WALD TEST

\begin{tabular}{lcc}
\hline Added variables to the model $(\mathrm{DV}=\mathrm{CCC})$ & $t$-statistic & Probability \\
\hline Corruption Perception Index (CPI) & 5.934 & $0.000^{*}$ \\
Control of Corruption Index (CCI) & 2.844 & $0.005^{*}$ \\
\hline Note. ${ }^{*}$ indicates a significant level at $1 \%, * * *$ indicates a significant level at \\
$10 \%$ & & \\
\hline Added variables to the model ( DV= NLB) & $t$-statistic & Probability \\
\hline Corruption Perception Index (CPI) & -2.878 & $0.004^{*}$ \\
Control of Corruption Index (CCI) & -2.191 & $0.028^{* *}$ \\
\hline Note. ${ }^{*}$ indicates a significance level at 1\%; ${ }^{* * *}$ indicates a significance level at $10 \%$
\end{tabular}

Table 11 shows the results of the Wald test. The results strongly rejected the null hypothesis, which posited that added corruption indexes have a coefficient equivalent to zero for CPI, and CCI, indicating that the regression models' explanatory power for the effect of corruption indicators on working capital management was enhanced through the introduction of corruption variables to the models.

\section{CONCLUSIONS}

Recent studies in finance have focused on the role of external variables in working capital management. By controlling the effect of internal variables, this study tried to investigate the relationship between corruption indexes and working capital management. According to the results, corruption affects the length of CCC; A high level of corruption indexes encourages managers to shorten the CCC length. The managers of sample firms reduce the level of investment in cash and cash equivalents when the levels of corruption indexes increase, an indication of a conservative working capital strategy by reducing the level of NLB. This study confirms the results of previous studies on the effects of corruption on working capital management.

\section{ENDNOTES}

1. The data available at: http://info.worldbank.org/governance/wgi/\#home

2. The data available at: https://www.transparency.org/ 


\section{REFERENCES}

Adnren, T. (2007). Econometrics. s.l.: Thomas Andren and Ventus Publishing Aps.

Anon. (2017). Trcansparency International. Retrieved from https://www.transparency.org

Appuhami, B. (2008). The Impact of Firms' Capital Expenditure on Working Capital Management: An

Empirical Study across Industries in Thailand. International Management Review, 4(1), 11-24.

Bates, W., Kahle, K., \& Stulz, M. (2009). Why Do U.S. Firms Hold So Much More Cash Than They

Used To? Journal of Finance, 64, 1985-2021.

Beck, T., Levine, R., \& Kunt, A. (2005). Law and Firms' access to Finance. American Law and Economics Review, 7(1), 211-252.

Brian, B., \& Smith, K. (1991). Comparison of working capital management practices in Australia and the United States. Global Finance Journal, 2(1-2), 27-54.

Caballero, J., Teruel, G., \& Solano, P. (2010, September). Working capital management in SMEs. Accounting and Finance, 50(3), 511-527.

Caballero, S., Teruel, P., \& Solano, P. (2014). Working capital management, corporate performance, and financial constraints. Journal of Business Research, 67(3), 332-338.

Caprio, L., Faccio, L., \& McConnell, M. (2013). Sheltering Corporate Assets From Political Extraction. Working paper, Purdue University. Journal of Law, Economics, and Organization, 29(2), 332354.

Chen, D., Li, S., Xiao, J., \& Zou, H. (2014). The Effects of Government Quality on Corporate Cash Holdings: Evidence from China. Journal of Corporate Finance, 27, 384-400.

Chiou, J., \& Cheng, L. (2006, September). The Determinants of Working Capital Management. Journal of American Academy of Business, 10(1), 149-155.

Claudiu, B., \& Anton, S. (2017). Is profitability driven by working capital management? evidence for high-growth firms from emerging Europe. Journal of Business Economics and Management, $18(6), 1135-1155$.

Cohen , D., \& Li , B. (2013). Why Do Firms Hold Less Cash? (s.1.). MIT Asia Conference in Accounting, Georgetown University.

Dittmar, A., \& Mahrt-Smith, J. (2007). Corporate Governance and the Value of Cash Holdings. Journal of Financial Economics, 83, 599-634.

Fan, H., Rui, O., \& Zhao, M. (2008). Public Governance and Corporate Finance:Evidence from corruption cases. Journal of Comparative Economics, 36, 343-364.

Fazzari, S., \& Petersen, B. (1993, Autumn). Working Capital and Fixed Investment: New Evidence on financing Constraints. Rand Journal of Economics, 24(3), 328-342.

Gill, A. (2011). Factors That Influence Working Capital Reqirment in Canada. Economics and Finance Review, 1(3), 30-40.

Greg, F., \& Krueger, T. (2005). An Analysis of Working Capital Management Results Across Industries. American Journal of Business, 20(2), 11-20.

Gujarati, D. N. (2003). Basic econometrics (4 ed.). New York: McGraw-Hill.

Hausman, J. (1978). Specification Tests in Econometrics. Econometrica, 46, 1251-1272.

Hung Mo, P. (2001). Corruption and Economic Growth. Journal of Comparative Economics, 29, 66-79.

Kaufmann, D., Kraay, A., \& Mastruzzi, M. (2012). Governance matters VIII: aggregate and individual governance indicators, 1996-2012 (s.1). Policy Research Working Paper No. 4978, World Bank.

La Porta, R., Lopez-de-Silanes, F., \& Schleifer, A. (1998). Law and Finance. Journal of Political Economy, 106(4), 1113-1155.

La Porta, R., Lopez, F., Shleifer, A., \& Vishny, R. (1997). Legal Determinants of External Finance. Journal of Finance, 52(3), 1131-1150.

Liu, F., Li, L., \& Xue, Y. (2009). Trust, Transaction Cost and Mode of Trade Credit. Economic Research Journal, 8, 60-72.

Mansoori, E., \& Mansoori, O. (2016). Working Capital Management Policies of Listed Companies in the Tehran Stock Exchange. International Business Management, 10(15), 3108-3112. 
Mansoori, E., \& Muhammad , J. (2012). Determinants of working capital management: Case of Singapore firms. Research Journal of Finance and Accounting, 3(11), 15-23.

Mansoori, E., \& Muhammad, J. (2012). The effect of working capital management on firm's profitability: Evidence from Singapore. Interdisciplinary Journal of Contemporary Research in Business, 4(5), 472-486.

Maxwell, C., Gitman, L., \& Smith, S. (1998). Working Capital Management and Financial-Service Consumption Preferences of US and Foreign Firms: A Comparison of 1979 and 1996 Preferences. Financial Practice and Education, 8(2), 46-52.

Niskanen, J., \& Niskanen, M. (2006). The Determinants of Corporate Trade Credit Policies in a BankDominated Financial Environment: The Case of Finnish Small Firms. European Financial Management, 12(1), 81-102.

Pankajk, J., Kuvvet, E., \& Pagano, M. (2012). Corruption's Impact on Liquidity, Investment Flows, and Cost of Capital. [Online].

Petersen, M., \& Rajan, R. (1997). Trade Credit: Theories and Evidence. Review of Financial Studies, 10(3), 661-691.

Richards, V., \& Laughlin, E. (1980, Spring). A Cash Conversion Cycle Approach to Liquidity Analysis. Financial Management, pp. 32-38.

Shin, H., \& Soenen, L. (1998). Efficiency of Working Capital and Corporate Profitability. Financial Practice and Education, 8(2), 37-45.

Shulman, J., \& Cox, R. (1985). An Integrative Approach to Working Capital Management. Journal of Cash Management, 5(6), 64-68.

Stulz, R. (2005). The Limits of Financial Globalization. The Journal of Finance, 60(4), 1595-1638.

Weinraub, H., \& Visscher, J. (1998). Industry Practice Relating To Aggressive Conservative Working. Journal of Financial and Strategic Decision, 11(2), 11-18

World, B. (2017). The Worldwide Governance Indicators(WGI) Project. [Online].

Zariyawati, M., M.N, A., Taufiq, H., \& Sazali, A. (2010). Determinants of Working Capital Management: Evidence from Malaysia. Dubay, s.n.

Zhu, H., \& Chen, X. (2006). Financial Development, Soft Financial Constraints and Corporate Investments. Accounting Research, 10, 64-71. 